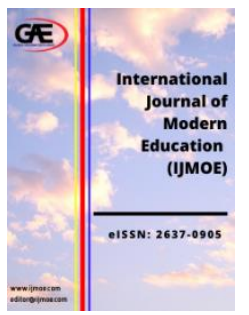

\author{
INTERNATIONAL JOURNAL OF \\ MODERN EDUCATION \\ (IJMOE) \\ www.ijmoe.com
}

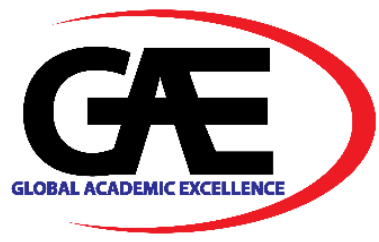

\title{
INFLUENCE OF WI-FI PERFORMANCE ON STUDENTS' SATISFACTION
}

Nor Ain Najwa Ismail ${ }^{1}$, Nur Atikah Armieza Khairul Nazmi ${ }^{2}$, Nur Aishah Abdul Razak ${ }^{3}$, Nurulnur Athirah Azhar ${ }^{4}$, Rozilawati Shaari ${ }^{5}$, Muhamad Saufiyudin Omar ${ }^{6 *}$

1 Department of Tourism and Hospitality, Politeknik Tuanku Syed Sirajuddin, Perlis, Malaysia. Email: ainnajwa9816@gmail.com

2 Department of Tourism and Hospitality, Politeknik Tuanku Syed Sirajuddin, Perlis, Malaysia. Email: atikaharmieza98@gmail.com

3 Department of Tourism and Hospitality, Politeknik Tuanku Syed Sirajuddin, Perlis, Malaysia. Email: nuraishahrazak127@gmail.com

4 Department of Tourism and Hospitality, Politeknik Tuanku Syed Sirajuddin, Perlis, Malaysia. Email: nurulnurathirah0922@gmail.com

5 Department of Tourism and Hospitality, Politeknik Tuanku Syed Sirajuddin, Perlis, Malaysia. Email: rozilawatishaari@gmail.com

6 Department of Tourism and Hospitality, Politeknik Tuanku Syed Sirajuddin, Perlis, Malaysia. Email: saufiyudin@yahoo.com

Corresponding Author

\section{Article Info:}

\section{Article history:}

Received date: 03.02.2021

Revised date: 10.03 .2021

Accepted date: 28.03.2021

Published date: 31.03 .2021

\section{To cite this document:}

Ismail, N. A. N., Nazmi, N. A. A. K., Razak, N. A. A., Azhar, N. A., Shaari, R., \& Omar, M. S. (2021). Influence of Wi-Fi Performance on Students' Satisfaction. Journal of Modern Education, 3(8), 226-237.

DOI: $10.35631 / \mathrm{IJMOE} .380018$

\begin{abstract}
:
Wi-Fi services provided by institutions are critical factors helping students in their learning process, especially during the COVID-19 pandemic. However, studies concerning Wi-Fi performance on students' satisfaction in Polytechnics Malaysia are limited. Hence, this study aims to investigate the influence of WiFi service quality on students' satisfaction, particularly in the Politeknik Tuanku Syed Sirajuddin (PTSS) context. Specifically, this study examines the influence of reliability, tangibility, responsiveness, assurance, and empathy on students' satisfaction towards Wi-Fi performance. Quantitative and single cross-sectional studies were employed. A total of 260 students responded to the survey questionnaires. Multiple regression analysis results revealed that reliability, tangibility, responsiveness, assurance, and empathy influence students' satisfaction. It shows that improving reliability, tangibility, responsiveness, assurance, and empathy is very important to increase students' satisfaction. The results also indicated that responsiveness is the primary factor influencing students' satisfaction. This study is hoped to enlighten the polytechnic management to improve $\mathrm{Wi}-\mathrm{Fi}$ performance for the students.
\end{abstract}




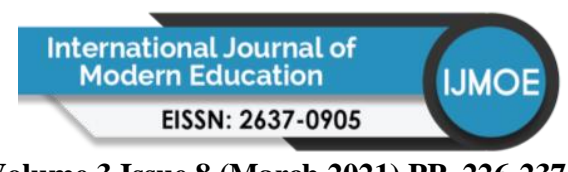

Volume 3 Issue 8 (March 2021) PP. 226-237 DOI: 10.35631/IJMOE.380018

Keywords:

Assurance, Empathy, Reliability, Responsiveness, Students' Satisfaction, Tangibility, Wi-Fi Performance

\section{Introduction}

During the COVID-19 pandemic, students rely heavily on Wi-Fi services provided by institutions to focus on their learning process. The local area network (LAN) is connected with high-frequency wireless using Wireless Fidelity Technology, known as Wi-Fi (Moate et al., 2017). It allows electronic devices, such as laptops, smartphones, and tablets, to connect to LAN and enables internet access to devices (Moate et al., 2017). The internet users in Malaysia have increased from $76.9 \%$ in 2016 to $87.4 \%$ in 2018 (Malaysian Communications \& Multimedia Commission (MCMC), 2018). Most of the users used internet services to assist and complete their work-related tasks, and $60.2 \%$ of the users were students using for studying and formal and informal learning process (MCMC, 2018). MCMC (2018) also stated that half of the internet users $(56.3 \%)$ used to read online publications, e-books, online magazines, newspapers, or journals. It shows that internet services are crucial, and Wi-Fi services excellence is critically important to assist students in studying and completing their assignments in the institutions.

Moate et al. (2017) also stated that wireless technology had become our saviour when it comes to communication and information sharing. Institutions already make it possible for students to connect their devices to the LAN through Wi-Fi, including those in developing countries. Therefore, it increases the institutions' opportunities to achieve teaching and learning objectives due to better Wi-Fi uploading and downloading speed. On the other hand, poor WiFi infrastructure leads to limited opportunities to accomplish the objectives (Moate at al., 2017). However, in the Malaysian polytechnics context, Wi-Fi facilities are not widely available (Yusuf et al., 2018). Students also claim that the internet connection is unsatisfactory in polytechnics and their hostels (Kumar et al., 2014). Therefore, a bad signal reception and connection interruption lead to students' dissatisfaction (Imran \& Wok, 2011).

According to Alsheyadi and Albalushi (2020), enhancing students' satisfaction has long been considered a critical strategic objective in higher learning institutions management. Students' satisfaction can be defined as individual students' feelings and attitudes towards the educational process, resulting from colleges' perceived service quality (Sary \& Herlambang, 2019). The most commonly used measure for service quality is SERVQUAL, developed by Parasuraman, Zeithaml, and Berry (1985). The concept of SERVQUAL is to investigate the gaps between what the supplier offers and customer expectations. Parasuraman et al. (1985) stated that SERVQUAL consists of five dimensions, namely reliability, tangibility, responsiveness, assurance, and empathy.

In this light, very few studies have focused on education sectors, especially in students' satisfaction on Wi-Fi performance (Berba \& Palaoag, 2018; Kumar et al., 2020; Leong \& Letchumanan, 2019). According to Masri et al. (2017), it is clearly essential to study the quality of technology, particularly wireless technology, because it is rarely studied. Therefore, this study investigates the influence of Wi-Fi performance on students' satisfaction, specifically in the Politeknik Tuanku Syed Sirajuddin (PTSS) context. In particular, the objective is to examine the influence of reliability, tangibility, responsiveness, assurance, and empathy on 


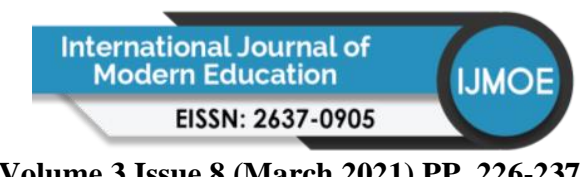

Volume 3 Issue 8 (March 2021) PP. 226-237

DOI: 10.35631/IJMOE.380018

students' satisfaction. The study results will benefit the students, lecturers, and polytechnic management in the future.

\section{Literature Review}

\section{Students' Satisfaction}

Students' satisfaction can be defined as the measurement of students' expectations and their perceptions of service performance (Alsheyadi \& Albalushi, 2020). In technology, students' satisfaction is the perception and attitudes that play a vital role in the acceptance or rejection of an innovation (Rogers, 2003). Satisfied students are a critical element in determining the success of the institution. One factor determining students' satisfaction is the system quality and support services offered by institutions (Alsheyadi \& Albalushi, 2020). It is because system quality and support services significantly affect the students' learning processes. One of the systems qualities and support services is Wi-Fi services. However, some institutions implement tight policies and limited Wi-Fi access, leading to a low satisfaction rating among students (Berba \& Palaoag, 2018). Besides, Berba and Palaoag (2018) also mentioned that no matter how fast the internet speed is, in certain circumstances, things will slow down to a crawl and it takes a significantly longer time than the usual for a page to load. Henceforth, the improvement of Wi-Fi services is critically important to improving students' satisfaction.

\section{Service Quality}

Since the $20^{\text {th }}$ century, service quality has been widely discussed. Its idea is still relevant today in an era of borderless world and globalisation to help organisations create differentiation and gain a competitive advantage (Ismail \& Yunan, 2015). Service quality can be defined as comparing customer expectations and services perceptions (Parasuraman et al., 1985). It is the overall services excellence's overall evaluation or attitude (Parasuraman et al., 1985). Service quality can also be determined by comparing customer service perceptions with the real service they receive (Siregar \& Suliantoro, 2019). In the technological context, service quality is interested not only in what (technical quality) they get as a service but also how (functional quality) they get it (Kasiri et al., 2017). In evaluating service quality, the crucial issue should be highlighted; why service quality should be evaluated. Gumussoy and Koseoglu (2016) claimed that service quality is measured with multiple dimensions, and each dimension may influence the overall service quality. According to Parasuraman et al. (1985), service quality comprises reliability, tangibility, responsiveness, assurance, and empathy.

\section{The Relationship between Service Quality Attributes and Students' Satisfaction}

Reliability is to consistently and reliably carry out the promised service (Shafiq et al., 2019). In the educational context, reliability refers to the institutions' ability to serve their students services, such as students can access institutions' services anytime and anywhere (Haming et al., 2019). Previous studies, such as Ideris et al. (2016), showed a significant relationship between reliability and students' satisfaction. Alsheyadi and Albalushi (2020) stated that reliability positively affects students' satisfaction. Meanwhile, Islam and Himel (2018) found that students' satisfaction is determined by reliability in their study.

Tangibility is defined as the quality of the institutions' physical facilities, machinery, materials, and workers' presence (Haming et al., 2019). Kundi et al. (2014) mentioned that physical installations, services, officers, and means of communication are tangible. Sani et al. (2014) claimed that students would lose their interest from a tangible dimension due to lack of 


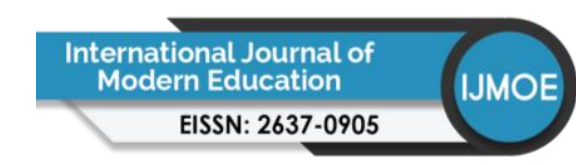

Volume 3 Issue 8 (March 2021) PP. 226-237

DOI: 10.35631/IJMOE.380018

facilities; for example, the completeness of academic support facilities and visually appealing environment, and the institution's appearance based on complete and modern equipment and support services. Previous studies showed that tangibility influences students' satisfaction. Alsheyadi and Albalushi (2020) found that tangibility influence students' satisfaction. Ideris et al. (2016) also found similar results in their study; tangibility plays an important element in influencing students' satisfaction.

Next is responsiveness. According to Iberahim et al. (2016), responsiveness is defined as responding to customer requirements timely and flexibly. Timely refers to the quality or habit of arriving or being ready on time or punctual (Iberahim et al., 2016). In this light, Saraswati (2018) stated that responsiveness plays an important role in gaining students trust, affecting students judgments on service quality. The staff response speed on students' complaints, the staff concern, and the desire to assist students needs are indicators of responsiveness. It shows a significant and positive relationship between responsiveness and students' satisfaction (Hasan et al., 2008). Osman et al. (2017) stated that responsiveness strongly influences students' satisfaction. Meanwhile, Alsheyadi and Albalushi (2020) and Ariyanto et al. (2020) also found that responsiveness influences students' satisfaction in their studies.

Ideris et al. (2016) stated that assurance is the service providers' ability to project trust and confidence to the institutions' services. They also argued that service providers must assure the delivery of knowledge courteously. In this light, Saraswati (2018) stated that assurance plays an important impact between staff and students. Staff must know how to answer students' questions, be polite to them, and make them feel safe in their transaction. Therefore, Osman et al. (2017) found that assurance shows the strongest influence on students' satisfaction in their study. Ideris et al. (2016) and Sani et al. (2014) also found a similar finding that assurance significantly and positively influences students' satisfaction.

The final element is empathy. Empathy is defined as the service providers' ability to give individual attention to the students (Ideris et al., 2016). Boon et al. (2016) claimed that understanding students' needs, willingness to help them, readiness to guide and advise the students and give personal attention are important factors in influencing students' satisfaction. Therefore, the staff's ability to communicate and pay attention well to students is much needed (Saraswati, 2018). In this light, Gregory (2019) found that empathy plays an important role in influencing students' satisfaction. Similarly, Ideris et al. (2016) also stated that empathy significantly and positively influences students' satisfaction. Hence, focusing on these elements is crucial to increase students' satisfaction. 


\section{Conceptual Framework and Research Hypotheses}

The proposed conceptual framework for this study is as follows:

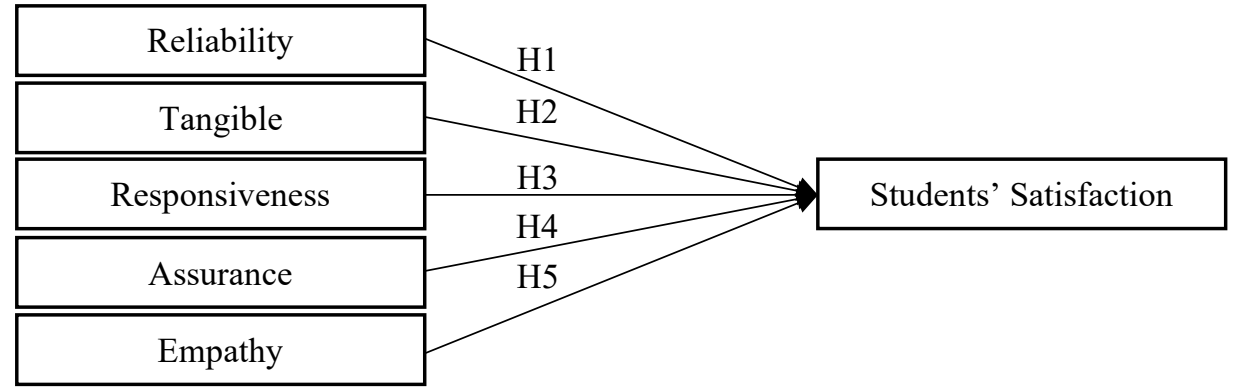

Figure 1: Research Framework

Source: Adapted from Parasuraman et al. (1985)

Based on the research framework, five hypotheses have been developed in this study:

H1: There is an influence of reliability on students' satisfaction towards Wi-Fi service.

$\mathrm{H} 2$ : There is an influence of tangibility on students' satisfaction towards Wi-Fi service.

H3: There is an influence of responsiveness on students' satisfaction towards Wi-Fi services.

H4: There is an influence of assurance on students' satisfaction towards Wi-Fi services.

H5: There is an influence of empathy on students' satisfaction towards Wi-Fi services.

\section{Research Methodology}

This study employed a quantitative research design and a single cross-sectional method. The unit of analysis was students from Politeknik Tuanku Syed Sirajuddin, comprising six departments with a total number of 3232 students for June 2020 session (Department of Students Affair, PTSS). Therefore, based on Krejcie and Morgan (1970), the minimum number of samples required was 341 respondents. This study employed stratified random sampling to determine the number of samples for each department. A minimum total number of $75,63,53$, 49, 59, and 42 respondents were required from the Department of Tourism and Hospitality (JPH), Department of Commerce (JP), Department of Electrical Engineering (JKE), Department of Information Technology and Communication (JTMK), Department of Design and Visual Communication (JRKV), and Department of Mechanical Engineering (JKM), respectively.

A questionnaire was adapted from previous scholars and divided into three sections to measure all variables. Section A focused on the respondents' demography (five items). Meanwhile, Section B focused on service quality, comprising reliability, tangibility, responsiveness, assurance, and empathy (25 items), adapted from Parasuraman et al. (1985), Davis, Bagozzi, and Warshaw (1989), and Masri et al. (2017). On the other hand, Section C focused on students' satisfaction (five items), adapted from Imran and Wok (2011). This study also employed a fivepoint Likert type scale, ranging from 1 (strongly disagree) to 5 (strongly agree).

Brislin (1970) introduced the back-translation method; since the original questionnaire was in English, it was translated from English to Malay Language and then retranslated from the Malay Language back to English to ensure the accuracy. In terms of validity, this study utilised 
Volume 3 Issue 8 (March 2021) PP. 226-237 DOI: 10.35631/IJMOE.380018

a content expert panel to verify all the items. Meanwhile, Cronbach's alpha coefficient was used to measure reliability. Cronbach's alpha coefficient results showed that all items were reliable, ranging from $\alpha=0.811$ to $\alpha=0.911$. More specifically, the value of students' satisfaction was $\alpha=0.911$, reliability $\alpha=0.811$, tangibility $\alpha=0.897$, responsiveness $\alpha=0.875$, assurance $\alpha=0.872$, and empathy $\alpha=0.875$.

In terms of data collection, this study employed the survey method, and the researchers used pen and paper to distribute the questionnaires. Before distributing the questionnaires, the researchers attached a cover letter informing the survey was voluntary, and all information gathered will be treated as confidential. This study also utilised the Statistical Package for Social Sciences (SPSS) version 22. The analysis used descriptive statistics, including frequency, percentage, mean, and standard deviation, and inferential analysis, such as reliability, Pearson correlation coefficients, and multiple regression analysis.

\section{Respondents' Demographic Profile}

A total of 260 respondents participated in this research, giving a response rate of $76 \%$. Female $(63.8 \%)$ was the highest respondents, followed by the male $(36.2 \%)$. In terms of age, the majority aged between $20-21$ years old (52.3\%) and 24 years old and above (1.5\%). Malay $(93.8 \%)$ was the major race in this study, followed by Siamese $(1.2 \%)$. Besides, JPH was the highest answering the questionnaires (25\%), followed by JP (21\%), JTMK (15\%), JKE (14\%), JKM (13\%), and JRKV (12\%). Table 1 shows the respondents' demographic profile.

Table 1: The Demographic Profile of the Respondents

\begin{tabular}{llll}
\hline Particular & & Frequency & Percent \\
\hline Gender & Male & 94 & 36.2 \\
& Female & 166 & 63.8 \\
Age & 18-19 Years Old & 66 & 25.4 \\
& 20-21 Years Old & 136 & 52.3 \\
& 22-23 Years Old & 54 & 20.8 \\
Race & 24 Years Old and Above & 4 & 1.5 \\
& Malay & 244 & 93.8 \\
& Chinese & 7 & 2.7 \\
& Indian & 6 & 2.3 \\
Department & Siamese & 3 & 1.2 \\
& JPH & 65 & 25 \\
& JP & 55 & 21 \\
& JKE & 37 & 14 \\
& JTMK & 38 & 15 \\
Total & JRKV & 32 & 12 \\
& JKM & 33 & 13 \\
\hline
\end{tabular}

\section{Results}

\section{Mean and Correlation Analysis Results}

Preliminary analyses were carried out before conducting the Pearson correlation analysis to ensure no violation of the assumptions of normality, linearity, multicollinearity, and homoscedasticity. The Pearson correlation analysis results showed that service quality, 


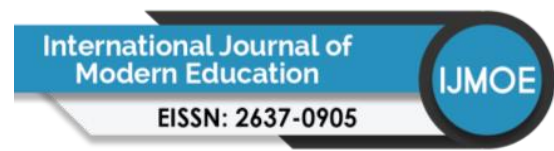

Volume 3 Issue 8 (March 2021) PP. 226-237

DOI: 10.35631/IJMOE.380018

comprising reliability, tangibility, responsiveness, assurance, and empathy, was significantly and positively correlated with students' satisfaction towards the Wi-Fi services in the PTSS context, at a significant level of 0.01 . More specifically, the correlation values of reliability and students' satisfaction were $r=0.872, p<0.001$, tangibility and students' satisfaction $r=0.880$, $p<0.001$, responsiveness and students' satisfaction $r=0.891, p<0.001$, assurance and students' satisfaction $r=0.809, p<0.001$, and empathy and students' satisfaction $r=0.859, p$ $<0.001$. The findings also revealed that the strongest and positive correlation on students' satisfaction was responsiveness, followed by tangibility, reliability, empathy, and assurance. Table 2 shows the correlation analysis of service quality and students' satisfaction.

Table 2: The Mean and Correlation Analysis Results

\begin{tabular}{lllllllll}
\hline Variables & Mean & Std. Dev. & $\mathbf{1}$ & $\mathbf{2}$ & $\mathbf{3}$ & $\mathbf{4}$ & $\mathbf{5}$ & $\mathbf{6}$ \\
\hline 1 Reliability & 2.456 & 1.060 & & & & & & \\
2 Tangibility & 2.486 & 1.084 & $.884^{* *}$ & & & & \\
3 Responsiveness & 2.533 & 1.119 & $.885^{* *}$ & $.913^{* *}$ & & & \\
4 Assurance & 2.650 & 1.138 & $.840^{* *}$ & $.852^{* *}$ & $.893^{* *}$ & & & \\
5 Empathy & 2.553 & 1.108 & $.862^{* *}$ & $.883^{* *}$ & $.931^{* *}$ & $.877^{* *}$ & & \\
6 Satisfaction & 2.528 & 1.152 & $.872^{* *}$ & $.880^{* *}$ & $.891^{* *}$ & $.809^{* *}$ & $.859^{* *}$ & \\
\hline
\end{tabular}

**Correlation is significant at the 0.01 level (1-tailed).

\section{Multiple Regressions Analysis}

After conducting the correlation analysis, this study conducted multiple regression analysis to answer Research Question 1. Based on the results, Model 1 presented the relationship between service quality attributes (reliability, tangibility, responsiveness, assurance, and empathy) and students' satisfaction. The results indicated that $R^{2}=0.842$, meaning that reliability, tangibility, responsiveness, assurance, and empathy are factors explaining $84.2 \%$ of the variance in students' satisfaction with $F=270.612, p<0.000$. In this case, the service quality attributes were significant towards the prediction of students' satisfaction, with beta values $\beta=0.294, p$ $<0.000 ; \beta=0.265, p<0.000 ; \beta=0.335, p<0.000 ; \beta=0.116, p<0.05$; and $\beta=0.166, p$ $<0.05$. Besides, reliability, tangibility, responsiveness, assurance, and empathy showed positive influences on students' satisfaction; hence, supporting Hypothesis 1, Hypothesis 2, Hypothesis 3, Hypothesis 4, and Hypothesis 5, perfectly achieving the research objectives. Table 3 shows the multiple regressions analysis results of this study.

Table 3: The Multiple Regressions Analysis Results

\begin{tabular}{llllll}
\hline Model 1 & B & Std. Error & Beta & t & Sig. \\
\hline Reliability & .319 & .064 & .294 & 4.959 & .000 \\
Tangibility & .282 & .072 & .265 & 3.920 & .000 \\
Responsiveness & .345 & .082 & .335 & 4.193 & .000 \\
Assurance & .113 & .047 & .116 & 2.384 & .018 \\
Empathy & .165 & .062 & .166 & 2.663 & .008 \\
\hline
\end{tabular}

Dependent Variable: Student's satisfaction

\section{Discussion}

Based on the results, Hypothesis 1 was supported, indicating a significant and positive influence of reliability on students' satisfaction. The finding was in line with Ariyanto et al. (2020) and Ideris et al. (2016) who also found that reliability influences students' satisfaction. The Wi-Fi services provided by PTSS were available at convenient hours, accessible, well 


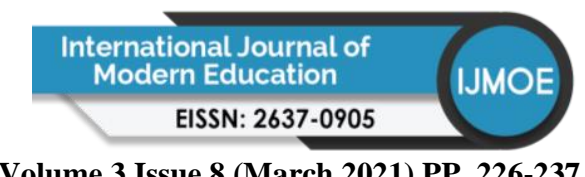

Volume 3 Issue 8 (March 2021) PP. 226-237

DOI: 10.35631/IJMOE.380018

operated, and consistent. Even though the students were satisfied with the services, but it was at a moderate level. Therefore, PTSS needs to upgrade Wi-Fi services to an optimum level to increase students' satisfaction, especially in terms of internet speed.

Secondly, Hypothesis 2 indicated that there is an influence of tangibility on students' satisfaction. Hence, Hypothesis 2 was also supported. The finding was also consistent with Alsheyadi and Albalushi (2020) and Ideris et al. (2016) who also found that tangibility influences students' satisfaction. The free Wi-Fi services provided were handy for the students to complete their tasks and assignments quickly. Besides, no obstacle was found while using the free Wi-Fi services.

Hypothesis 3, indicating the influence of responsiveness on students' satisfaction towards WiFi services, was also supported. The finding was consistent with Alsheyadi and Albalushi (2020) and Ariyanto et al. (2020) who also found that responsiveness influences students' satisfaction. Students felt that the Wi-Fi services provided were secured when they were using it. They also could easily search for information anytime and anywhere.

The Hypothesis 4 result indicated that assurance significantly and positively influences students' satisfaction, which was in line with Ideris et al. (2016) and Sani et al. (2014). Therefore, Hypothesis 4 was supported. The staff in charge of the free Wi-Fi services at PTSS were trusted, knowledgeable, and confident; thus, giving the students a safe feeling when using the services.

Lastly, the Hypothesis 5 result indicated that empathy significantly and positively influences students' satisfaction. Hence, Hypothesis 5 was supported. It was consistent with Alsheyadi and Albalushi (2020) and Ideris et al. (2016) who found that empathy significantly and positively influences students' satisfaction. Students were concerned with personal caring and individualised attention. Therefore, they liked using the free Wi-Fi services provided to update their social media platform status and talk about their experiences using Wi-Fi services at PTSS. They also encouraged their friends to use the services because of no obstacles while using the services. These are the factors contributing to the influence of empathy on students' satisfaction.

\section{Conclusion and Recommendation}

In sum, this study found that service quality, comprising reliability, tangibility, responsiveness, assurance, and empathy, significantly and positively influence students' satisfaction in the PTSS context. The finding also indicated that responsiveness was the most significant influence on students' satisfaction than other elements. It implies that enhancing the element of responsiveness is crucial to increase students' satisfaction in the future. Therefore, the findings contributed to the polytechnic management to improve Wi-Fi service for the students in the context of Politeknik Tuanku Syed Sirajuddin.

Nevertheless, this study has a few limitations. The first limitation is the variables used. Since the study results showed other factors influencing students' satisfaction besides service quality, future studies may include other elements to measure students' satisfaction. Secondly, this study focuses on PTSS students only; hence, it cannot be generalised to the entire polytechnics in Malaysia as well as the other education institution in Malaysia. Therefore, future studies may include the other polytechnics and education institution in Malaysia. 


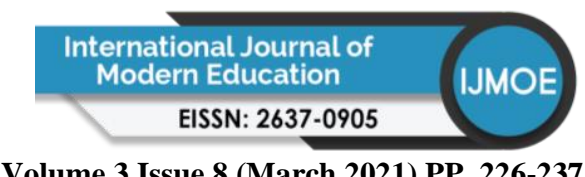

Volume 3 Issue 8 (March 2021) PP. 226-237 DOI: 10.35631/IJMOE.380018

\section{References}

Alsheyadi, A. K., \& Albalushi, J. (2020). Service Quality of Student Services and Student Satisfaction: The Mediating Effect of Cross-Functional Collaboration. TQM Journal, 32(6), 1197-1215.

Ariyanto, E., Aima, M. H., Nurani, A., \& Sari, M. (2020). Analysis of the Effect of Service Quality Dimensions on Student Satisfaction in Master of Management of Mercu Buana. IOSR Journal of Business and Management, 22(6), 5-13.

Berba, E. M., \& Palaoag, T. D. (2018). Examining Customer Satisfaction on Wi-Fi Internet Services in a Higher Education Institution. Journal of Advanced Research in Dynamical and Control Systems, 10(11 Special Issue), 146-150.

Boon, T., Shukur, M., \& Bassim, A. (2016). Evaluation of Service Quality of Private Higher Education using Service Improvement Matrix. Procedia-Social and Behavioral Sciences, 224, 132-140.

Brislin, R. W. (1986). The Wording and Translation of Research Instruments. In Lonner, J. W., \& Berry, J. W. (Eds.), Cross-cultural Research and Methodology Series, 8,137-164. Thousand Oaks, CA, US: Sage Publications, Inc.

Davis, F. D., Bagozzi, R. P., \& Warshaw, P. R. (1989). User Acceptance of Computer Technology: A Comparison of Two Theoretical Models. Management Science, 35(8), 982-1003.

Gregory, J. L. (2019). Applying SERVQUAL: Using Service Quality Perceptions to Improve Student Satisfaction and Program Image. Journal of Applied Research in Higher Education, 11(4), 788-799.

Gumussoy, C. A., \& Koseoglu, B. (2016). The Effects of Service Quality, Perceived Value and Price Fairness on Hotel Customers' Satisfaction and Loyalty. Journal of Economics, Business and Management, 4(9), 523-527.

Haming, M., Murdifin, I., Syaiful, Z. A., \& Putra, A. H. P. K. (2019). The Application of SERVQUAL Distribution in Measuring Customer Satisfaction of Retails Company. Journal of Distribution Science, 17(2), 25-31.

Hasan, H. F. A., Ilias, A., Rahman, R. A., \& Razak, M. Z. A. (2008). Service Quality and Student Satisfaction: A Case Study at Private Higher Education Institutions. International Business Research, 1(3), 163-175.

Iberahim, H., Taufik, M. N. K., Mohd Adzmir, A. S., \& Saharuddin, H. (2016). Customer Satisfaction on Reliability and Responsiveness of Self Service Technology for Retail Banking Services. Procedia Economics and Finance, 37(16), 13-20.

Ideris, M. S. K., Yi, L. T., Rodzi, S. M., Romle, A. R., Zabri, M. A. H. M., \& Mahamad, A. A. (2016). Students' Satisfaction on Facilities in Universiti Utara Malaysia. World Applied Sciences Journal, 34(6), 795-800.

Imran, A. I., \& Wok, S. (2011). Satisfaction with the Free Wireless Connection among Muslim University Students, 1-11.

Islam, S., \& Himel, S. H. (2018). Services Quality and Students' Satisfaction: A Study on the Public Higher Education Institutions (HEIs) of Bangladesh. Journal of Business Studies, $X X X I X(2), 135-149$.

Ismail, A., \& Yunan, Y. S. M. (2015). Service Quality as a Predictor of Customer Satisfaction and Customer Loyalty. Logforum, 12(4), 269-283.

Kasiri, L. A., Guan Cheng, K. T., Sambasivan, M., \& Sidin, S. M. (2017). Integration of Standardization and Customization: Impact on Service Quality, Customer Satisfaction, and Loyalty. Journal of Retailing and Consumer Services, 35(6), 91-97. 


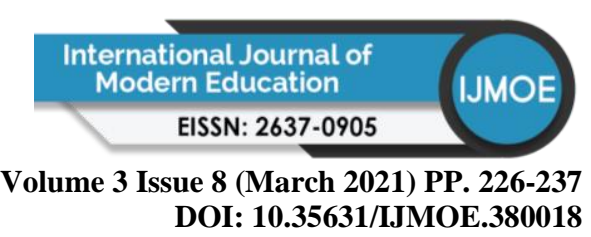

Krejcie, R. V., \& Morgan, D. W., (1970). Determining Sample Size for Research Activites. Educational and Psychological Measurement, 30(3), 607-610.

Kumar, J. A., Muniandy, B., \& Yahaya, W. A. J. W. (2014). Exploring the perception and acceptance of information and communication technology (ICT) in the Classroom for Polytechnic Students. Journal of Teaching and Education, 3(3), 175-185.

Kumar, J. A., Rajamanickam, S., \& Osman, S. (2020). Exploring the Use of Mobile Apps for Learning: A Case Study on Final Year Engineering Undergraduates in Malaysia. ASM Science Journal, 13(3), 63-67.

Kunachagaran, K., Govindaraju, V., Ramakrishnan, S., \& Hishan, S. S. (2017). End Users' Perception on Public Wi-Fi System: A Study Conducted in Kuala Lumpur, Malaysia. Advanced Science Letters, 23(9), 9265-9270.

Kundi, G. M., Khan, M. S., Phil, M., Qamar, S., Qureshi, A., Khan, Y., \& Akhtar, R. (2014). Impact of Service Quality on Customer Satisfaction in Higher Education Institutions. Industrial Engineering Letters, 4(3), 23-28.

Leong, Y. M., \& Letchumanan, C. (2019). Effective Learning in Higher Education in Malaysia by Implementing Internet of Things Related Tools in Teaching and Introducing IoT Courses in Curriculum. In 2019 1st International Conference on Artificial Intelligence and Data Sciences (AiDAS), 152-157.

Malaysian Communications \& Multimedia Commission (MCMC). (2018). Internet Users Survey 2018: Statistical Brief Number Twenty-Three. Internet Users Survey, 1-39.

Masri, N., Anuar, F. I., \& Yulia, A. (2017). Influence of Wi-Fi Service Quality towards Tourists' Satisfaction and Dissemination of Tourism Experience. Journal of Tourism, Hospitality \& Culinary Arts, 9(2), 383-398.

Moate, K. M., Chukwuere, J. E., \& Mavhungu, M. B. (2017). The Impact of Wireless Fidelity on Students' Academic Performance in a Developing Economy. In Proceedings of International Academic Conferences (No. 4607490). International Institute of Social and Economic Sciences.

Osman, A. R., Sarkar, J. B., \& Islam, E. M. S. (2017). Revisiting Student Satisfaction through SERVQUAL: Private Tertiary Education Perspective. British Journal of Education, 5(11), 119-137.

Parasuraman, A., Zeithaml, V. A., \& Berry, L. L. (1985). A Conceptual Model of Service Quality and its Implications for Future Research. Journal of Marketing, 49(4), 41-50.

Rogers, E. M. (2003). Diffusion of innovations. New York: Free Press.

Samsuddin, S. F., Bolong, J., Omar, S. Z., D'Silva, J. L., Sahharon, H., \& Shaffril, H. A. M. (2015). Examining the Impact of Demographic Factors on the Attitude of Rural Communities in Malaysia towards Village Wi-Fi Services. Asian Social Science, 11(18), 134-143.

Sani, A. M., Osman, A., \& Daud, M. S. (2014). Student Satisfaction towards Service Quality of Front Office Staff: A Perspective of Public Higher Education Institution in Malaysia. Advances in Environmental Biology, 8(4), 543-548.

Saraswati, R. A. (2018). Dominant Factors of Service Quality to Stimulate Purchase Intention: Study of Starbucks in Jakarta. (Doctoral dissertation, President University).

Sary, F. T., \& Herlambang, O. (2019). E-learning program effectiveness on students' learning satisfaction at Telkom University Bandung in Social Sciences on Sustainable Development for World Challenge: The First Economics, Law, Education and Humanities International Conference. KnE Social Sciences, 271-280. 
Volume 3 Issue 8 (March 2021) PP. 226-237 DOI: 10.35631/IJMOE.380018

Shafiq, A., Mostafiz, M. I., \& Taniguchi, M. (2019). Using SERVQUAL to Determine Generation Y's Satisfaction towards Hoteling Industry in Malaysia. Journal of Tourism Futures, 5(1), 62-74.

Siregar, S. D., \& Suliantoro, H. (2019). Improving Customer Satisfaction of Wi-Fi Id Service with Service Quality Method. Industrial Engineering Online Journal, 7(4), 1-10.

Wahab, N. A., Ahmad, M. R., Isa, A. A. M., Malik, R. F., \& Esa, M. R. M. (2019). Wi-Fi Temporal Coverage: Analysis of Socio-Economics Influences in Malaysia. IOP Conference Series: Earth and Environmental Science, 228(1), 1-15.

Yusuf, N. R., Ahmad, A. R., \& Awang, M. M. (2018). Professionalism Practice among Lecturers in Polytechnic in Malaysia. International Journal of Academic Research in Business and Social Sciences, 8(2), 636-645.

\section{Appendix 1: Questionnaire of Dimensions of SERVQUAL Components and Student Satisfaction}

Please circle the number that best describes or reflect you based on the following statements by using the scale rating as followed; $1=$ Strongly Disagree, $2=$ Disagree, $3=$ Uncertain, $4=$ Agree, 5= Strongly Agree.

\begin{tabular}{|c|c|}
\hline Dimension & Statement (item) \\
\hline Reliability & $\begin{array}{l}\text { Wi-Fi services provided at PTSS are easily accessible. } \\
\text { Wi-Fi services provided at PTSS are reliable and well managed. } \\
\text { Wi-Fi services provided at PTSS are consistent and stable. } \\
\text { Wi-Fi services provided at PTSS are available at convenient } \\
\text { hours. } \\
\text { Wi-Fi services provided at PTSS have a sound internet speed. }\end{array}$ \\
\hline Tangibility & $\begin{array}{l}\text { I easily use the free Wi-Fi services provided at PTSS. } \\
\text { I am able to complete my assignments efficiently by using the } \\
\text { free Wi-Fi services provided at PTSS. } \\
\text { I have no difficulties accessing the free Wi-Fi services provided } \\
\text { at PTSS. } \\
\text { I think the free Wi-Fi service provided at PTSS is very } \\
\text { beneficial for the students. } \\
\text { I feel my assignment quality improves with the free Wi-Fi } \\
\text { provided at PTSS. }\end{array}$ \\
\hline Resp & $\begin{array}{l}\text { I will give positive feedback to others about the free Wi-Fi } \\
\text { services provided at PTSS. } \\
\text { I can search for information that I need at anytime and anywhere } \\
\text { using the free Wi-Fi services provided at PTSS. } \\
\text { I think my effectiveness in completing my assignments } \\
\text { increases with the free Wi-Fi services provided at PTSS. } \\
\text { I feel secure using the free Wi-Fi services provided at PTSS. } \\
\text { I benefit from the free Wi-Fi services provided at PTSS for my } \\
\text { assignments. }\end{array}$ \\
\hline Assurance & $\begin{array}{l}\text { The staff in charge of the free Wi-Fi services at PTSS give me } \\
\text { confidence in using the services. } \\
\text { Students can rely on the staff in charge of the free Wi-Fi services } \\
\text { provided at PTSS. }\end{array}$ \\
\hline
\end{tabular}


Volume 3 Issue 8 (March 2021) PP. 226-237 DOI: 10.35631/IJMOE.380018

\begin{tabular}{|l|l|}
\hline & $\begin{array}{l}\text { I feel safe when downloading any apps using the free Wi-Fi } \\
\text { services provided at PTSS. } \\
\text { The staff in charge of the free Wi-Fi services provided at PTSS } \\
\text { are knowledgeable to answer my enquiries. } \\
\text { The staff in charge of the free Wi-Fi services provided at PTSS } \\
\text { can be trusted. }\end{array}$ \\
\hline Empathy & $\begin{array}{l}\text { I will encourage my friends to use the free Wi-Fi services } \\
\text { provided at PTSS. } \\
\text { I will write a review on websites about the free Wi-Fi services } \\
\text { provided at PTSS. } \\
\text { I will update social media platforms about my experiences using } \\
\text { the free Wi-Fi services provided at PTSS. } \\
\text { Nothing is stopping me from using the free Wi-Fi services } \\
\text { provided at PTSS. } \\
\text { My interactivity with the free Wi-Fi services provided at PTSS } \\
\text { is clear and understandable. }\end{array}$ \\
\hline $\begin{array}{l}\text { I am satisfied with the availability of the free Wi-Fi services } \\
\text { provided at PTSS. } \\
\text { I am satisfied with the reliability of the free Wi-Fi services } \\
\text { provided at PTSS. } \\
\text { I am satisfied with the connection quality of the free Wi-Fi } \\
\text { services provided at PTSS. } \\
\text { I am satisfied with the effectiveness of the free Wi-Fi services } \\
\text { provided at PTSS. } \\
\text { I am satisfied with the free Wi-Fi services provided at PTSS to } \\
\text { search for my studies' relevant information. }\end{array}$ \\
\hline
\end{tabular}

